\title{
Mosquito cell line glycoproteins: an unsuitable model system for the Plasmodium ookinete-mosquito midgut interaction?
}

\author{
Simon Wilkins*1,2 and Peter F Billingsley1,3
}

\begin{abstract}
Background: Mosquito midgut glycoproteins may act as key recognition sites for the invading malarial ookinete. Effective transmission blocking strategies require the identification of novel target molecules. We have partially characterised the surface glycoproteins of two cell lines from two mosquito species; Anopheles stephensi and Anopheles gambiae, and investigated the binding of Plasmodium berghei ookinetes to carbohydrate ligands on the cells. Cell line extracts were run on SDS-PAGE gels and carbohydrate moieties determined by blotting against a range of biotinylated lectins. In addition, specific glycosidases were used to cleave the oligosaccharides.

Results: An. stephensi 43 and An. gambiae 55 cell line glycoproteins expressed oligosaccharides containing oligomannose and hybrid oligosaccharides, with and without a1-6 core fucosylation; N-linked oligosaccharides with terminal Galß1-3GalNAc or GalNAcß1-3Gal; O-linked a/ßGalNAc. An. stephensi 43 cell line glycoproteins also expressed $N$-linked Galß1-4R and O-linked Galß1-3GalNAc. Although P. berghei ookinetes bound to both mosquito cell lines, binding could not be inhibited by GlcNAc, GalNAc or Galactose.

Conclusions: Anopheline cell lines displayed a limited range of oligosaccharides. Differences between the glycosylation patterns of the cell lines and mosquito midgut epithelial cells could be a factor why ookinetes did not bind in a carbohydrate inhibitable manner. Anopheline cell lines are not suitable as a potential model system for carbohydrate-mediated adhesion of Plasmodium ookinetes.
\end{abstract}

\section{Background}

Malaria is caused by parasitic protozoa of the genus Plasmodium which are transmitted to humans by Anopheles spp. (Diptera:Culicidae) mosquitoes. The life cycle of Plasmodium is complex with asexual development in the human host as well as sexual and asexual development in the mosquito [1]. Strategies for the development of malaria vaccine candidates target the stages found within humans e.g. the asexual erythrocytic stages, however vaccine candidates have also been developed against both the sexual stages of malaria in the mosquito (reviewed in [2]) and against the mosquito vector itself (reviewed in [3]). The most developed candidate vaccine is RTS, S which can reduce the multiplicity of infection in African adults and is currently the subject of a Phase 3 trial initi-

*Correspondence: simon.wilkins@med.monash.edu.au

1 Department of Biology, Imperial College of Science Technology and Medicine, South Kensington, London, SW7 2BB, UK

Full list of author information is available at the end of the article ated in May 2009 [4]. In the mosquito, the main barrier to the ookinete is the mosquito midgut and passage through the midgut epithelium is the critical step for successful establishment of a Plasmodium infection in the mosquito $[5,6]$. Successful transmission is dependent on vector:parasite compatibility [7], as well as mosquito age and parasite density in the blood meal [8].

Oligosaccharides on midgut glycoproteins are receptors for microbial attachment in a number of insects systems [9-11]. Mosquito midgut glycoproteins typically are heavily glycosylated with a high proportion of $N$-linked GlcNAc- and GalNAc-terminal oligosaccharides [12] and carbohydrates are key elements in the interaction of both Plasmodium falciparum and Plasmodium vivax in Anopheles tessellatus [13], and Plasmodium gallinaceum in Aedes aegypti [14]. More recent work has identified a family of lectin-like proteins termed Plasmodium berghei lectin adhesive-like protein (PbLAP1-5) expressed in $P$. berghei ookinetes and gametocytes which could be 
involved in binding carbohydrate ligands on the midgut epithelial cell surface [15]. Sugar epitopes may provide potential transmission blocking targets as a monoclonal antibody raised against a GalNAc containing midgut glycoprotein blocked Plasmodium yoelli infectivity in Anopheles stephensi [16]. Further identification of effective transmission blocking strategies requires a fuller understanding of the molecular interactions between the parasite and the mosquito cells, and this includes the exposed carbohydrate structures [17].

Cell lines have been used as model systems for lectinmediated adhesion of parasites, for example Entamoeba histolytica binding to Caco-2 cells and Giardia lamblia binding to Int-407 cells $[18,19]$. The cell lines were substitutes for the usual host cells and the interactions between the parasites and the cell lines were inhibited by carbohydrates. In an insect system, the identification of a midgut carbohydrate ligand for Bacillus thuringiensis toxin [20], has led to studies using insect cell lines in binding assays to understand the molecular interaction between the $B$. thuringiensis toxin and the host cell [21].

In the present study, mosquito cell lines were investigated as a potential model system for Plasmodium ookinete binding to the mosquito midgut. Initially the glycosylation profile of the membrane glycoproteins of two anopheline mosquito cell lines was investigated. Secondly we assessed whether ookinetes would bind to the cell lines in a carbohydrate-dependent manner. Identification of any ookinete binding ligand molecules would be a useful step in the progress towards identification of vaccine target molecules to prevent the transmission of malaria by mosquitoes.

Using an array of lectins and glycosidases we show the presence of a number of different oligosaccharides on glycoproteins from two anopheline cell lines; An. stephensi 43 and $A n$. gambiae 55. In addition we show that P. berghei ookinetes bind to monolayers of both anopheline cell lines but the binding is not inhibitable by monosaccharides. Finally we discuss the implications of the different pattern of glycosylation observed in the cells compared with the mosquito midgut, the ookinete binding to the cell lines, and the suitability of the cell lines as a model for the ookinete:mosquito midgut interaction.

\section{Methods}

\section{Mosquito cell lines}

Two mosquito cell lines, An. stephensi 43, and An. gambiae 55, were derived from embryonic larval cells [22,23]. Cell lines were cultured at in an incubator at $28^{\circ} \mathrm{C}$ in medium optimised for cell growth. Cell lines were tested 20-26 passages from liquid nitrogen stocks (An. stephensi 43 cell lines -stock passage number 210; An. gambiae 55 cell lines -stock passage number 150). Both An. stephensi 43 and $A n$. gambiae 55 cell lines were cultured in a 1:1 mix of Modified Kitamura's/Varma and Pudney's VP 12 medium $\left(\mathrm{MKVP}_{12}\right)$ [22] supplemented with $10 \%(\mathrm{v} / \mathrm{v})$ heat inactivated foetal calf serum (Gibco) and .0.5\% (v/v) penicillin-streptomycin-neomycin solution (Gibco).

\section{Sample preparation}

A T75 culture flask (Gibco) for each cell line was grown to near confluence. Cells were dislodged from the flask surface with a cell scraper (Gibco) and the cell suspension added to a $15 \mathrm{ml}$ Falcon tube and spun at $800 \mathrm{rpm}$ to pellet the cells. The supernatant was discarded and cell pellet was resuspended and centrifuged twice at $800 \mathrm{rpm}$ with physiologically buffered saline (PBS; $0.15 \mathrm{M} \mathrm{NaCl}$, $0.027 \mathrm{M} \mathrm{KCl}, 0.01 \mathrm{M} \mathrm{Na}_{2} \mathrm{HPO}_{4}, \mathrm{pH} \mathrm{7.4)}$ to remove cell culture media. Cells were homogenised in a $0.1 \mathrm{ml}$ glass/ glass homogeniser (Jencons) in PBS containing 5\% v/v Triton X-100 (Sigma). Protein concentrations were calculated against a Bovine Serum albumin (BSA Fraction V; Sigma) standard [24].

\section{SDS-PAGE and lectin blotting}

Mosquito cell line samples containing $2 \mu \mathrm{g}$ protein in 10 $\mu \mathrm{l}$ PBS TX-100 were loaded with an equal volume of sample buffer onto 10 or $12.5 \%$ SDS-PAGE gels [25]. Proteins were transferred onto $0.45 \mu$ Nitrocellulose membrane (NCM) and stained in $0.1 \% \mathrm{w} / \mathrm{v}$ Ponceau $\mathrm{S}$ in $5 \% \mathrm{v} / \mathrm{v}$ acetic acid (Sigma). Marker lanes were removed and stained with colloidal gold (Protogold ${ }^{\circ}$, British BioCell International) according to manufacturer's instructions. NCMs were blocked overnight at $4^{\circ} \mathrm{C}$ in TBS-T $(0.1 \% \mathrm{v} / \mathrm{v} 0.05 \mathrm{M}$ Tris- $\mathrm{HCl}, 0.15 \mathrm{M} \mathrm{NaCl}, 0.1 \mathrm{v} / \mathrm{v} \%$ Tween 20, $\mathrm{pH} 7.5$ ). Transferred lanes containing mosquito and control glycoproteins were cut lengthways into strips for multiple testing of a single lane. NCMs were incubated for $45 \mathrm{~min}$ in $20 \mu \mathrm{g} / \mathrm{ml}$ biotinylated lectin solution (all lectins sourced from Vector Labs, UK), rinsed, and then incubated for 45 min in streptavidin-linked alkaline phosphatase (0.2 U/ $\mathrm{ml}$ ) in TBS-T. Alkaline phosphatase (AP; Vector Labs., UK) was developed according to manufacturers instructions using a combination of BCIP (5-Bromo-4-Chloro3'-Indolyl Phosphate sodium salt) and NBT (Nitro-Blue Tetrazolium chloride) as a substrate (Vector Labs., UK). Lectin binding controls consisted of lectin only or streptavidin-linked AP only. Positive control glycoproteins were used as controls for both lectin blotting and sugar inhibitions. These were prepared by either running glycoproteins $(2 \mu \mathrm{g}$ per well) on SDS-PAGE gels and transferring to NCM as described above or glycoproteins (5-10 $\mu \mathrm{g})$ were dot-blotted directly onto NCM then blocked before use. Molecular weights $(\mathrm{kDa})$ of mosquito cell line proteins were estimated using protein marker standards from 3-5 different experiments. Lectins used in this study, their respective positive controls, and specificities are shown in Table 1. Abbreviations for lectins used 
Table 1: Lectins used and their specificities

\begin{tabular}{|c|c|c|c|c|}
\hline Lectin & Abbreviation & Sugar specificity & Positive control & Reference \\
\hline Concanavalin A & Con A & a-mannose, a-glucose & SBA, Ovalbumin & [46] \\
\hline $\begin{array}{l}\text { Wheat Germ } \\
\text { Agglutinin }\end{array}$ & WGA & $\begin{array}{c}\text { (GlcNAc) }{ }_{2} \text {, Sialic acid, } \\
\text { GalNAc }\end{array}$ & Ovalbumin & [47] \\
\hline $\begin{array}{l}\text { Dolichos biflorus } \\
\text { agglutinin }\end{array}$ & DBA & a-GalNAc & ASM & [48] \\
\hline Soybean agglutinin & SBA & $a, \beta-G a l N A c$, Gal & ASM & [49] \\
\hline Peanut agglutinin & PNA & Galß1-3GalNAc & ASM, BSA-T & {$[50]$} \\
\hline $\begin{array}{l}\text { Artocarpus } \\
\text { integrifola agglutinin }\end{array}$ & $J A C$ & $\begin{array}{c}\text { Gal } \beta 1-3 G a l N A c \\
\text { GalNAc } \beta 1-3 \text { Gal, } \\
\text { GalNAc }\end{array}$ & ASM, BSA-T & {$[51,52]$} \\
\hline $\begin{array}{l}\text { Phaesolus vulgaris } \\
\text { agglutinin }\end{array}$ & PHA & Galß1-4GIcNAc & ASF & [53] \\
\hline $\begin{array}{l}\text { Ricinus communis } \\
\text { agglutinin }\end{array}$ & $\mathrm{RCA}_{\|}$ & Galß1-4GIcNAc & ASF & [54] \\
\hline $\begin{array}{l}\text { Maackia amirensis } \\
\text { lectin }\end{array}$ & $M A L_{\|}$ & Sialic acida2-3Gal & Mouse blood & [55] \\
\hline $\begin{array}{l}\text { Sambuca nigra } \\
\text { agglutinin }\end{array}$ & SNA & Sialic acida2-6Gal & Fetuin & [56] \\
\hline $\begin{array}{l}\text { Ulex europaeus } \\
\text { agglutinin }\end{array}$ & UEA $_{1}$ & Fuca1-2Gal & Mucin & [57] \\
\hline $\begin{array}{l}\text { Aleutia aurantia } \\
\text { agglutinin }\end{array}$ & AAL & Fuca1-3/6 & Mucin & [58] \\
\hline
\end{tabular}

Positive controls for each lectin were dot blotted and treated as described in materials and methods.

in this study: AAL, Aleutia aurantia agglutinin; Con A, Concanavalin A; DBA, Dolichos biflorus agglutinin; JAC, Artocarpus integrifolia agglutinin; $\mathrm{MAL}_{\mathrm{II}}$, Maackia amurensis lectin; PHA, Phaesolus vulgaris agglutinin; $\mathrm{RCA}_{\mathrm{II}}$, Ricinus communis agglutinin; PNA, Peanut agglutinin; SBA, Soybean agglutinin; SNA, Sambuca nigra agglutinin; $\mathrm{UEA}_{\mathrm{I}}$, Ulex europaeus agglutinin; WGA, wheat germ agglutinin.

\section{Carbohydrate inhibition}

Cell samples and control glycoproteins were prepared and transferred onto NCM as described above. Lectin staining of mosquito cell line glycoproteins and controls was carried out in the presence of mono- and di- saccharides to inhibit lectins and thereby confirm the specificity of the interactions between the lectins used and the oligosaccharides. Each sugar was added to biotinylated lectin solutions at an excess concentration of $100 \mathrm{mM}$ to ensure complete abrogation of lectin binding. Lectin staining was carried out as described above.

\section{Glycosidase treatments}

Cell samples and control glycoproteins were prepared and transferred onto NCM as described above. Digestion of exposed oligosaccharides in situ was carried out using an Immunetics miniblotter (Cambridge, MA, USA) to deliver $125 \mu \mathrm{l}$ of reaction mixture containing endo- or exo-glycosidases directly onto the NCM strips; optimum enzyme concentrations and specificities are shown in Table 2. Enzymes were added in excess amounts to ensure full cleavage during treatments. The blotter was sealed and incubated for $24 \mathrm{~h}$ at $37^{\circ} \mathrm{C}$ in a humid atmosphere under constant gentle agitation. After extensive rinsing with TBS, strips were stained with biotinylated lectins as described above.

\section{Chemical deglycosylation of MV glycoproteins}

NCMs containing transferred cell line glycoproteins were cut lengthways into two strips, rinsed in $50 \mathrm{mM}$ sodium acetate buffer $(\mathrm{pH} 4.5)$ and then treated with $20 \mathrm{mM}$ periodic acid in buffer for $1 \mathrm{~h}$ in the dark at $23^{\circ} \mathrm{C}$. NCMs were rinsed with acetate buffer then incubated in $50 \mathrm{mM}$ sodium borohydride in PBS for $30 \mathrm{~min}$ at room temperature. Strips were then washed in TBS-T and lectin stained.

\section{Plasmodium berghei ookinete cultures}

P. berghei (clone 2.34L) (originally from Dr. D. Walliker, University of Edinburgh) were maintained by cyclical passage in female Theiler's original (TO) mice and $A n$. stephensi mosquitoes, and ookinetes prepared as described previously [26]. Parasitaemia levels were moni- 
Table 2: Summary of glycosidases and running conditions used for digestion of mosquito cell line glycoproteins.

\begin{tabular}{|c|c|c|c|c|c|}
\hline $\begin{array}{c}\text { Enzyme } \\
\text { (enzyme number) }\end{array}$ & Abbreviation & Cleavage site & $\begin{array}{l}\text { Enzyme } \\
\text { Conc. }\end{array}$ & $\begin{array}{l}\text { Incubation } \\
\text { Buffer (pH) }\end{array}$ & Reference \\
\hline $\begin{array}{c}\text { Peptide-N-glycosidase F } \\
\text { (EC 3.2.2.18) }\end{array}$ & PNGase F & $\begin{array}{c}N \text {-linked } \\
\text { oligosaccharides-Asn }\end{array}$ & $50 U$ & $\begin{array}{l}0.5 \mathrm{M} \text { sodium } \\
\text { phosphate }(7.5)\end{array}$ & [59] \\
\hline $\begin{array}{c}\text { Peptide-N-glycosidase A } \\
\text { (EC 3.5.1.52) }\end{array}$ & PNGase A & $\begin{array}{c}N \text {-linked } \\
\text { oligosaccharides-Asn }\end{array}$ & $2.5 \mathrm{mU}$ & $\begin{array}{l}50 \mathrm{mM} \text { sodium } \\
\text { citrate, sodium } \\
\text { phosphate }(5.0)\end{array}$ & [60] \\
\hline $\begin{array}{c}\text { Endo- } \beta \text {-glucosaminidase } \mathrm{H} \\
\text { (EC 3.2.1.96) }\end{array}$ & Endo $\mathrm{H}$ & $\begin{array}{c}\text { Oligomannose/ } \\
\text { hybrid } \\
\text { oligosaccharides-Asn }\end{array}$ & $50 \mathrm{U}$ & $\begin{array}{l}0.5 \mathrm{M} \text { sodium citrate } \\
(5.5)\end{array}$ & [61] \\
\hline $\begin{array}{c}\text { Endo-a-acetylgalactosaminidase } \\
\text { (EC 3.2.1.92/3.2.1.110) }\end{array}$ & O-glycanase ${ }^{\mathrm{TM}}$ & $\begin{array}{l}\text { Galß1-3GalNAca1- } \\
\text { Ser/Thr }\end{array}$ & $82-112 \mathrm{mU}$ & $\begin{array}{l}10 \mathrm{mM} \text { sodium } \\
\text { citrate, sodium } \\
\text { phosphate }(6.0)\end{array}$ & {$[62]$} \\
\hline $\begin{array}{c}\text { a-N-acetylgalactosaminidase } \\
\text { (EC 3.2.1.49) }\end{array}$ & $a-A G A$ & GalNAca1-3R/Ser/Thr & $625 \mathrm{mU}$ & $\begin{array}{l}100 \text { mM sodium } \\
\text { citrate, sodium } \\
\text { phosphate }(3.5-4)\end{array}$ & [63] \\
\hline $\begin{array}{c}\beta \text {-Galactosidase } \\
\text { (EC 3.2.1.23) }\end{array}$ & - & $\begin{array}{l}\text { Galß1-3GlcNAc } \\
\text {-Glc/Man }\end{array}$ & $4 \mathrm{mU}$ & $\begin{array}{l}20 \text { mM sodium } \\
\text { citrate, sodium } \\
\text { phosphate }(6.0)\end{array}$ & [64] \\
\hline $\begin{array}{c}\text { Neuraminidase } \\
\text { (EC 3.2.1.18) }\end{array}$ & - & Sialic acida2-3,6,8R & $25 \mathrm{mU}$ & $\begin{array}{c}0.5 \mathrm{M} \text { sodium citrate } \\
(4.5)\end{array}$ & [65] \\
\hline
\end{tabular}

tored by Giemsa stained blood smears and slides were examined under a light microscope $\times 40$ objective using oil immersion.

\section{Ookinete: mosquito cell line binding assays}

MTT (3- [4,5-dimethylthiazol-2-yl)-2,5-diphenyl tetrazolium bromide) is a yellow substrate which is cleaved by active mitochondria in living cells to yield a purple end product, therefore dead cells are not detectable using this substrate [27]. Initially a standard curve of MTT production against ookinete number was calculated. Ookinete numbers were estimated on a haemocytometer. Ookinetes were then diluted in PBS and a two-fold serial manner, and MTT (Sigma; $5 \mathrm{mg} / \mathrm{ml}$ sterile filtered in PBS) was added (10 $\mu \mathrm{l}$ per $100 \mu \mathrm{l}$ medium/PBS) to each dilution, and the mixtures vortexed and incubated for $4 \mathrm{~h}$ at $37^{\circ} \mathrm{C}$. Acid-isopropanol $(100 \mu \mathrm{l}$ of $0.04 \mathrm{~N} \mathrm{HCl}$ in isopropanol (BDH) or an equal amount of the initial volume) was added to each well to dissolve MTT crystals. Cell debris was pelleted and the supernatant plated out in triplicate onto 96 well plates (Nunc). Plates were read on either an Anthos HTIII or Molecular Devices Vmax microtitreplate reader at $570 \mathrm{~nm}$ and at the reference wavelength of $620 \mathrm{~nm}$. Absorbance values at $620 \mathrm{~nm}$ were subtracted from the absorbance values at $570 \mathrm{~nm}$.

Binding assays were set up using anopheline mosquito cell lines. Numbers of cultured cells were estimated on a haemocytometer and 300,000 cells were added to form a monolayer in sterile 96 well plates (Greiner). Excess medium was then removed and the plates washed with PBS using a Vacu-pette 96 (DBM Scientific) and the cells fixed with methanol for $30 \mathrm{~s}$. Non-specific protein binding sites were then blocked with $1 \% \mathrm{w} / \mathrm{v}$ BSA in PBS for 1 $h$ at $37^{\circ} \mathrm{C}$, and the cells were further washed three times with PBS as above. Ookinete cell numbers per $\mu \mathrm{l}$ of culture were estimated on a haemocytometer and 20,000 ookinetes were added per well and incubated on cell monolayers for $6 \mathrm{~h}$ at $19^{\circ} \mathrm{C}$. A $6 \mathrm{~h}$ incubation time was chosen to match the escape time of mature ookinetes from the mosquito midgut lumen [28]. Following incubation, plates were washed three times in PBS as above, then $100 \mu \mathrm{l}$ PBS were added to each well. MTT assay was carried out as described above with controls of a PBS blank and fixed cells alone. Binding assays were carried out three times with 5-6 technical replicates for each data point. Data were analysed by one way ANOVA with post hoc Dunnett's test in GraphPad Prism.

The toxicity of carbohydrates to be used in binding assays were tested in Eppendorf tubes by adding $500 \mu \mathrm{l}$ of monosaccharide solutions to $500 \mu$ l ookinete cultures containing approx. approximately 20,000 ookinetes. Carbohydrates were tested at concentrations of $100 \mathrm{mM}, 250$ $\mathrm{mM}$ and $500 \mathrm{mM}$. Ookinetes were exposed to the carbohydrates for $6 \mathrm{~h}$ at $19^{\circ} \mathrm{C}$ then an MTT assay carried out as above. 


\section{Results}

Proteins of mosquito cell line samples

Anopheline cell line extracts contained proteins that were detected with Protogold ${ }^{\circ}$ (Figure 1), but did not bind any lectins tested. The An. stephensi 43 cell line sample contained twelve major bands detected only with Protogold ${ }^{\circ}$ (approximately 206, 133, 103, 92, 77, 68, 63, 53, 50, 46, 28, and $27 \mathrm{kDa}$ )(Figure 1, lane 1) and an additional twenty six which were detected with lectins. Ten major bands were detected with Protogold in the An. gambiae 55 cell line sample (approximately 145, 108, 77, 74, 58, 55, 53, 35, 34, and $30 \mathrm{kDa}$ )(Figure 1, lane 2) in addition to sixteen proteins detected with lectins.

\section{Characteristics of An. stephensi $\mathbf{4 3}$ cell line glycoproteins}

Six lectins bound to glycoproteins from An. stephensi 43 cells; Con A, SNA, RCA II, PNA, JAC and AAL (Figure 2A and $2 \mathrm{~B})$. WGA, UEA, $\mathrm{MAL}_{\mathrm{II}}$ and PHA did not bind to any glycoprotein (Figure 2B). Additionally SBA did not recognise any glycoprotein (data not shown). Twelve major bands (approximately 370, 138, 117, 103, 87, 67, 59, $52,48,45,39$, and $33 \mathrm{kDa}$ ) and two minor bands (approximately 33.5 and $30 \mathrm{kDa}$ ) were recognised by Con A (Figure $2 \mathrm{~A}$, lane 6 ). Binding to each of these glycoproteins was abolished by $100 \mathrm{mM}$ mannose and reduced by 100 $\mathrm{mM}$ glucose (Figure 2A, lanes 7 and 8). In situ digestion with PNGase F removed all Con A binding (Figure 3A, lane 7). Endo $\mathrm{H}$ treatment removed Con A binding, with

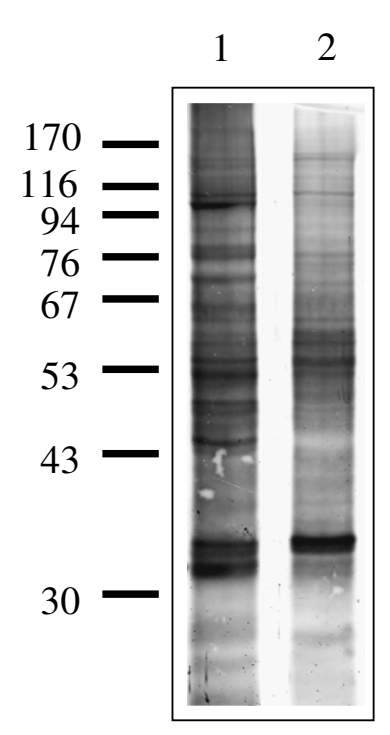

Figure $1 \mathrm{Gold}$ staining of mosquito cell line protein samples. Lane 1 An. stephensi 43 cell line protein sample (4 $\mu$ g loaded); lane 2 An. gambiae 55 cell line protein sample ( $4 \mu \mathrm{g}$ loaded). Molecular weight marker positions are shown in $\mathrm{kDa}$. Representative blot shown of 4 separate experiments. the exception of the 87,59 , and $33 \mathrm{kDa}$ glycoproteins, where binding was only partially reduced (Figure 3A, lane 8). PNGase A reduced Con A binding intensities of all glycoproteins (Figure 3B, lane 5), but to a lesser extent than Endo $\mathrm{H}$. Chemical deglycosylation with periodate removed all Con A binding (Figure 3B, lane 6). AAL bound strongly to six glycoproteins from An. stephensi 43 cells (approximately. 370, 138, 117, 87, 79, and $59 \mathrm{kDa}$ ) and also faintly to four glycoproteins (approximately. 52, 45 , 42, and $36 \mathrm{kDa}$ ) (Figure 2B, lane 1). Competitive inhibition by $100 \mathrm{mM}$ fucose removed AAL binding to all gly-

A

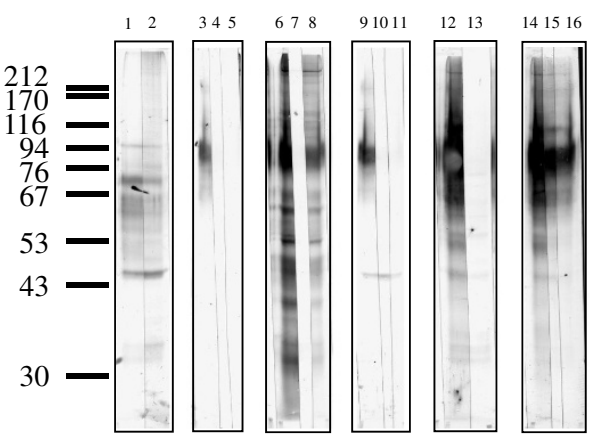

B

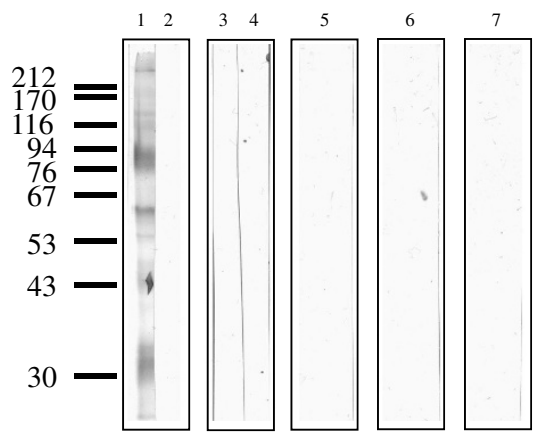

Figure 2 Lectin blotting with a range of lectins to An. stephensi 43 cell line glycoproteins with and without competitive sugar inhibitions. The position of molecular weight markers run concurrently are shown, values in $\mathrm{kDa}$. Two $\mu \mathrm{g}$ of protein were loaded to each well. Figure 2A: Lane 1 SNA, and with $100 \mathrm{mM}$ Sialic acid (lane 2); lane 3 RCA with $100 \mathrm{mM}$ galactose (lane 4), with $100 \mathrm{mM}$ melibiose (lane 5); lane 6 Con A, with 100 mM mannose (lane 7), with 100 mM glucose (lane 8); lane 9 PNA, with 100 mM galactose (lane 10), 100 mM melibiose (lane 11); lane 12 JAC, with 100 mm GalNAC (lane 13); lane 14 JAC, with 100 mM galactose (lane 15), 100 mM melibiose (lane 16). Figure 2B: Lane 1 AAL, with 100 fucose (lane 2); lane 3 WGA; with 100 mM GlcNAc (lane 4), lane $5 \mathrm{UEA}_{1}$; lane $6 \mathrm{MAL}_{\|}$; lane $7 \mathrm{PHA}$. Representative blot shown of 3-5 separate experiments. 
coproteins (Figure 2B, lane 2). In situ treatment with PNGase F removed all AAL binding sites from the glycoproteins (data not shown) whereas in situ Endo $\mathrm{H}$ and PNGase A did not alter binding of AAL (Figure 3B, lanes 2 and 3$)$.

JAC bound to nine glycoproteins, four that were strongly stained (approximately 370, 122, 111, and 87) and five that were only faintly stained (approximately 55 , 52, 48, 34 and 33) (Figure 2A, lane 12 and 14). Binding to the 370,122 , and $87 \mathrm{kDa}$ glycoproteins was abolished in the presence of $100 \mathrm{mM}$ GalNAc (Figure 2A, lane 13), but only reduced in the presence of $100 \mathrm{mM}$ galactose and $100 \mathrm{mM}$ melibiose (Figure 2A, lanes 15 and 16). Binding

\section{A}

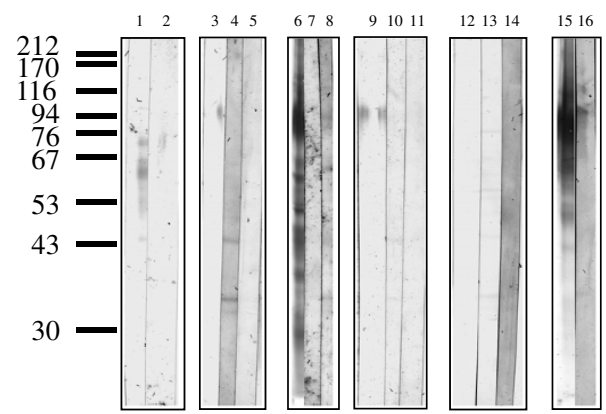

B

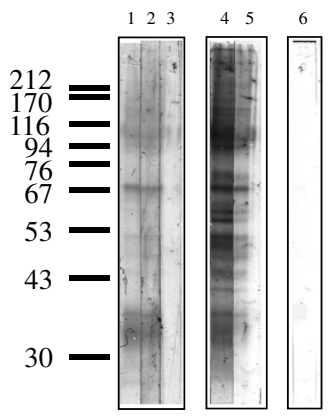

Figure 3 Lectin blotting with a range of lectins to An. stephensi 43 cell line glycoproteins before and after in situ glycosidase treatments. The position of molecular weight markers run concurrently are shown, values in $\mathrm{kDa}$. Two $\mu \mathrm{g}$ of protein were loaded to each well. Figure 3A: Lane 1 SNA, after neuraminidase (lane 2); lane 3 RCA $A_{\|}$, after $\beta$ galactosidase (lane 4), after PNGase $F$ (lane 5); lane 6 Con A, after PNGase F (lane 7), after Endo H (lane 8); lane 9 PNA, after O-glycanase ${ }^{\text {TM }}$ (lane 10), after PNGase F (lane 11); lane 12 DBA, after a AGA (lane 13), after PNGase $F$ (lane 14); lane 15 JAC, after PNGase $F$ (lane 16). Figure 3B: Lane 1 AAL, after Endo H (lane 2), after PNGase A (lane 3); lane 4 Con A, after PNGase A (lane 5), after periodate (lane 6). Representative blot shown of 3-5 separate experiments. to the 55 and $52 \mathrm{kDa}$ glycoproteins was inhibited by 100 $\mathrm{mM}$ GalNAc and $100 \mathrm{mM}$ melibiose and partially inhibited by $100 \mathrm{mM}$ galactose. The binding intensity of the 48 kDa glycoprotein was reduced with $100 \mathrm{mM}$ GalNAc and $100 \mathrm{mM}$ galactose but abolished with $100 \mathrm{mM}$ melibiose. The 34 and $33 \mathrm{kDa}$ glycoproteins had reduced binding intensities with $100 \mathrm{mM}$ GalNAc but both $100 \mathrm{mM}$ galactose and $100 \mathrm{mM}$ melibiose inhibited binding (Figure 2A, lanes 13, 15 and 16). In situ treatment with $O$-glycanase ${ }^{\mathrm{TM}}$ did not alter binding intensity (data not shown), whereas PNGase F reduced the binding intensity of JAC to all glycoproteins (Figure 3A, lane 15 and 16). DBA did not bind to any glycoprotein and treatments in situ with $\alpha$ AGA and PNGase $F$ revealed several faintly staining bands (Figure 3A, lanes 12, 13 and 14).

Both $\mathrm{RCA}_{\mathrm{II}}$ and PNA bound to an $87 \mathrm{kDa}$ glycoprotein, and binding was inhibited competitively by $100 \mathrm{mM}$ galactose and $100 \mathrm{mM}$ melibiose (Figure 2A). Treatment with PNGase $\mathrm{F}$ or $\beta$-galactosidase removed binding of $\mathrm{RCA}_{\mathrm{II}}$ to the glycoprotein. However, two new bands were detectable at 44 and $33 \mathrm{kDa}$ after $\beta$-galactosidase treatment (Figure 3A, lane 4). Treatments with $O$-glycanase ${ }^{\text {тм }}$ and PNGase F removed PNA and RCA II binding to the 87 $\mathrm{kDa}$ glycoprotein (Figure 3A, lanes 10 and 5 respectively). The sialic acid-specific lectin SNA, bound to four glycoproteins (approximately 95, 72.5, 61,5 and $44 \mathrm{kDa}$ ) and two which were only faintly stained (approx. 60 and 58 $\mathrm{kDa}$ ) (Figure 2A, lane 1). Competitive sugar inhibition with sialic acid did not reduce binding, and an unexpected additional band was detectable at $33 \mathrm{kDa}$ (Figure 2A, lane 2). In situ neuraminidase treatment abolished SNA binding sites (Figure 3A, lanes 1 and 2).

\section{Characteristics of An. gambiae $\mathbf{5 5}$ cell line glycoproteins}

A different pattern of binding was observed with glycoproteins from An. gambiae 55 cells, the lectins Con A, JAC, and AAL bound to several glycoproteins, and the lectins DBA, SBA, SNA, MAL ${ }_{\text {II }}, \mathrm{RCA}_{\mathrm{II}}$, PHA, WGA, and $U_{E A}$ faintly stained several glycoproteins (Figure 4A and $4 \mathrm{~B})$. Con A bound strongly to twelve glycoproteins (approximately 182, 143, 114, 101, 76, 65, 57.5, 55, 50, 48, 38 , and $35 \mathrm{kDa}$ ), all of which except the $76 \mathrm{kDa}$ band were no longer detectable after inhibition by $100 \mathrm{mM}$ mannose (Figure 4A, lanes 6 and 7). Competitive inhibition by 100 $\mathrm{mM}$ glucose reduced Con A binding intensities to all glycoproteins (Figure 4A, lane 8). Both PNGase F and periodate treatments removed Con $A$ binding to all glycoproteins (Figures 5A, lane 7 and Figure 4B, lane 4). Endo $\mathrm{H}$ treatment in situ reduced binding intensities of almost all glycoproteins except the 45 and $35 \mathrm{kDa}$ glycoproteins which showed partial resistance to Endo $\mathrm{H}$ treatment (Figures 5A, lane 8). PNGase A treatment reduced 
the binding intensities of all glycoproteins (Figure 5B, lane 5).

$\mathrm{MAL}_{\mathrm{II}}$ and PHA bound very faintly to the 76 and 35 kDa glycoproteins (Figure 4B, lanes 8 and 9). SNA also bound to the $35 \mathrm{kDa}$ glycoproteins (Figure 4A, lane 1), but in the presence of $100 \mathrm{mM}$ sialic acid, the binding intensity of the $35 \mathrm{kDa}$ glycoprotein had unexpectedly increased. Two additional bands (58 and $53 \mathrm{kDa}$ ) were detectable in the presence of $100 \mathrm{mM}$ sialic acid (Figure $4 \mathrm{~A}$, lane 2). The $35 \mathrm{kDa}$ glycoprotein was resistant (Figure $5 \mathrm{~A}$, lane 2). $\mathrm{RCA}_{\mathrm{II}}$ also bound to the 76 and $35 \mathrm{kDa}$ glyco-

A

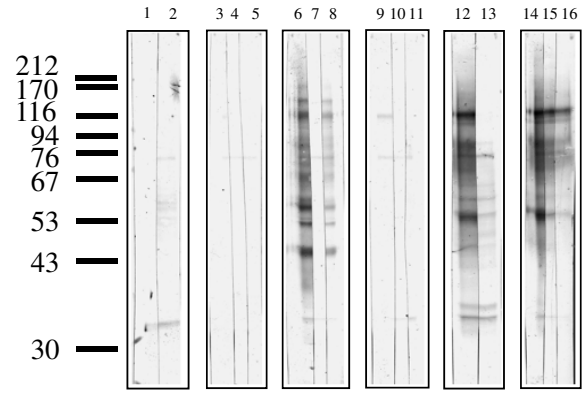

B

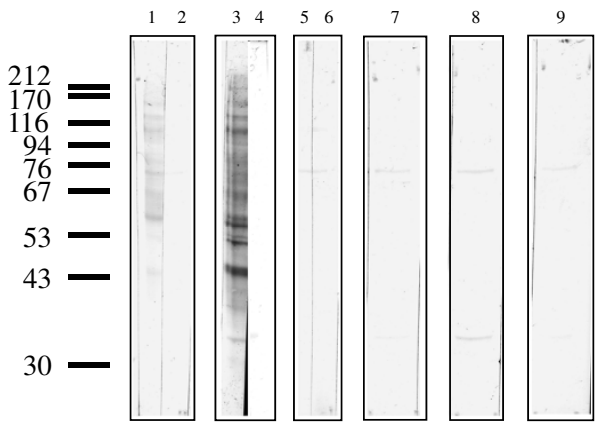

Figure 4 Lectin blotting with a range of lectins to An. gambiae 55 cell line glycoproteins with and without competitive sugar inhibitions. The position of molecular weight markers run concurrently are shown, values in $\mathrm{kDa}$. Two $\mu \mathrm{g}$ of protein were loaded to each well. Figure 4A: Lane 1 SNA, and with $100 \mathrm{mM}$ Sialic acid (lane 2); lane 3 RCA $\|_{\| \prime}$ with $100 \mathrm{mM}$ galactose (lane 4), with $100 \mathrm{mM}$ melibiose (lane 5); lane 6 Con A, with $100 \mathrm{mM}$ mannose (lane 7), with 100 mM glucose (lane 8); lane 9 SBA, with 100 mM galactose (lane 10), 100 mM GalNAc (lane 11); lane $12 \mathrm{JAC}$, with $100 \mathrm{mM}$ GalNAc (lane 13); lane $14 \mathrm{JAC}$, with $100 \mathrm{mM}$ galactose (lane 15), $100 \mathrm{mM}$ melibiose (lane 16). Figure 4B: Lane 1 AAL, with 100 fucose (lane 2); lane 3 Con A, and after periodate treatment (lane 4); lane 5 WGA, with 100 mM GlcNAc (lane 6); lane 7 UEA lane $8 \mathrm{MAL}_{\|}$; lane $9 \mathrm{PHA}$. Representative blot shown of 3-5 separate experiments. proteins, but $100 \mathrm{mM}$ galactose and $100 \mathrm{mM}$ melibiose did not inhibit binding (Figure 4A, lanes 3, 4, and 5). After $\beta$-galactosidase treatment a new band was detected with a molecular weight of $35 \mathrm{kDa}$ (Figure 5A, lane 4). WGA bound very faintly to the $76 \mathrm{kDa}$ glycoprotein, although this was not inhibited by $100 \mathrm{mM}$ GlcNAc (Figure 4B, lane 5 and 6). AAL bound to four glycoproteins (approximately $\mathrm{kDa} 143,114,76$, and $57.5 \mathrm{kDa}$ ), and binding was inhibited by $100 \mathrm{mM}$ fucose (Figure 4B, lanes 1 and 2) and removed by PNGase $\mathrm{F}$ (data not shown). The fucose specific-lectin, $\mathrm{UEA}_{\mathrm{I}}$, bound very faintly to the $35 \mathrm{kDa}$ glycoprotein (Figure 4B, lane 7).

A

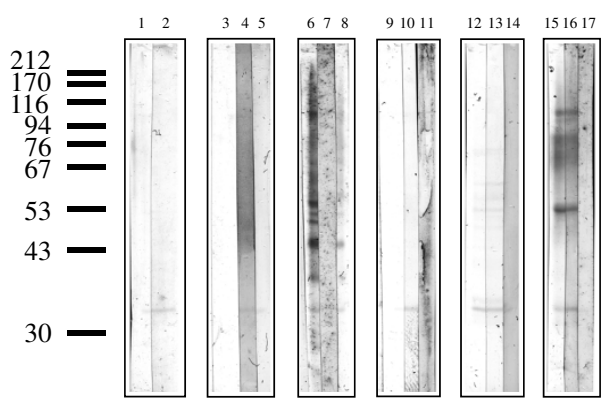

B

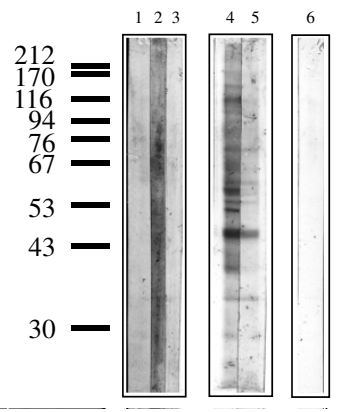

Figure 5 Lectin blotting with a range of lectins to An. gambiae 55 cell line glycoproteins before and after in situ glycosidase treatments. The position of molecular weight markers run concurrently are shown, values in $\mathrm{kDa}$. Two $\mu \mathrm{g}$ of protein were loaded to each well. Figure 5A: Lane 1 SNA, after neuraminidase (lane 2); lane $3 R^{2} A_{\| \prime}$, after $\beta$ galactosidase (lane 4), after PNGase $F$ (lane 5); lane 6 Con A, after PNGase F (lane 7), after Endo H (lane 8); after SBA (lane 9); after O-glycanase ${ }^{\text {TM }}$ (lane 10), after PNGase F (lane 11); lane 12 DBA, after a AGA (lane 13), after PNGase F (lane 14); lane $15 \mathrm{JAC}$, after O-glycanase ${ }^{\mathrm{TM}}$ (lane 16), after PNGase $F$ (lane 17). Figure 5B: Lane 1 AAL, after Endo $H$ (lane 2), after PNGase A (lane 3); lane 4 Con A, after PNGase A (lane 5); lane 6 after periodate treatment. Representative blot shown of 3-5 separate experiments. 
SBA bound faintly to three glycoproteins with molecular weights of 114, 76, and $35 \mathrm{kDa}$ (Figure 4A, lane 9). Binding was not inhibited by either $100 \mathrm{mM}$ galactose or $100 \mathrm{mM}$ GalNAc (Figure 4A, lanes 10 and 11). DBA bound to glycoproteins with molecular weights of 76, $53.5,36$, and $35 \mathrm{kDa}$. DBA binding to these glycoproteins was not altered by either $\alpha$ AGA or PNGase F treatments, and the binding was very faint (Figure 5A, lanes 13 and 14). JAC bound strongly to several glycoproteins (approximately $114,86.5,76,61,57.5,53.5$, and $35 \mathrm{kDa}$ ) and faintly to the $101 \mathrm{kDa}$ glycoprotein (Figure 4A, lane 12). Binding to the $114,101,76$, and $57.5 \mathrm{kDa}$ glycoproteins was inhibited by $100 \mathrm{mM}$ GalNAc, whereas binding to the $61,53.5$, and $35 \mathrm{kDa}$ glycoproteins was reduced by $100 \mathrm{mM}$ GalNAc (Figure 4A, lane 13). Galactose inhibited binding to the 53.5 and $35 \mathrm{kDa}$ glycoproteins, whereas $100 \mathrm{mM}$ melibiose reduced the binding intensity of the $53.5 \mathrm{kDa}$ glycoprotein and inhibited the binding of JAC to the $35 \mathrm{kDa}$ glycoprotein. Binding to all other glycoproteins by JAC was not altered by $100 \mathrm{mM}$ galactose and $100 \mathrm{mM}$ melibiose (Figure 4A, lanes 15 and 16). $O$ glycanase $^{\mathrm{Tm}}$ did not reduce binding intensities, but in situ treatment with PNGase F removed all JAC binding (Figure $5 \mathrm{~A}$, lanes 16 and 17 ).

\section{Ookinete binding to anopheline mosquito cell lines}

MTT production was linearly and directly proportional to the number of ookinetes seeded into microplate wells (Figure 6A). MTT production by ookinetes was not significantly reduced by monosaccharides at concentrations up to $500 \mathrm{mM}$ (data not shown). A significant increase in MTT absorbance was detected when ookinetes were incubated with mosquito cells compared with MTT absorbance of mosquito cells alone (one-way ANOVA with post hoc Dunnett's test, $\mathrm{p}<0.01$ ) (Figure 7). However the change in absorbance values was small suggesting very weak binding and the absorbance values were at the limit of detection. Absorbance values (570nm-620 $\mathrm{nm}$ ) of $\sim 0.03$ corresponded to binding of around 2000 ookinetes from the original 20,000 added per well (Figure 6B). Ookinete binding to fixed An. stephensi 43 cells was tested in the presence of $12.5 \mathrm{mM}, 50 \mathrm{mM}, 250 \mathrm{mM}$ GlcNAc, galactose and GalNAc. GlcNAc, galactose and GalNAc did not significantly reduce ookinete binding at any concentration tested (Figure 7). Binding to An. gambiae 55 cells showed an identical profile of weak binding which was not significantly inhibited by carbohydrates (data not shown).

\section{Discussion}

The use of plant-derived lectins to analyse and identify carbohydrates is a widely used technique employed in many different systems of host-parasite interactions $[29,30]$. Lectins have been essential and reliable tools in
A

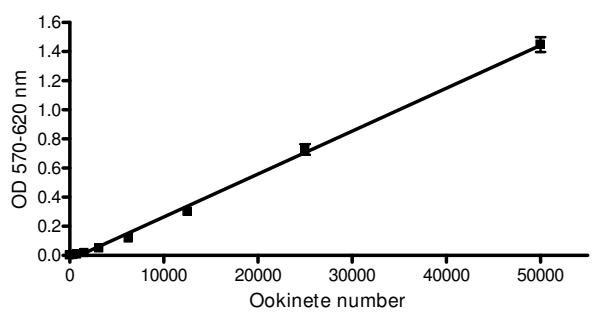

B

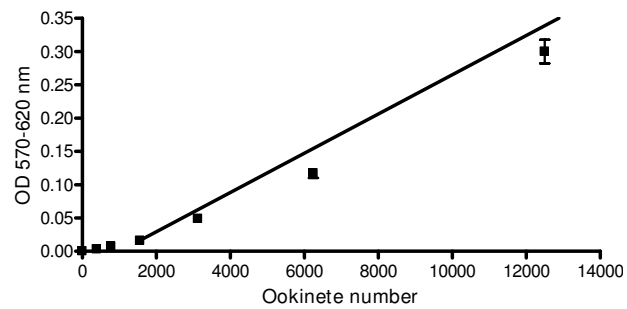

Figure 6 Standard curve showing MTT cleavage against number of ookinetes. Ookinete numbers were estimated on a haemocytometer. Ookinetes were then diluted in PBS and a two-fold serial manner, and MTT was $(5 \mathrm{mg} / \mathrm{ml})$ added to each dilution, and the mixtures vortexed and incubated for $4 \mathrm{~h}$ at $37^{\circ} \mathrm{C}$. After incubation the resultant solutions were plated out on microwell plates. Figure 6A: Linear regression trend line is shown. Each point corresponds to the mean of six wells, bars indicate standard deviation of means. Trend line $\mathrm{R}^{2}=$ 0.9974. Figure 6B: The lower limit of the linear range of the standard curve was at an absorbance reading of 0.02 which corresponds to around 1500 ookinetes.

the investigation into malaria: mosquito interactions over a considerable period of time [31,32]. The aim of this study was to investigate the glycosylation of the membrane glycoproteins of two mosquito cell lines, with the intention of testing the cell lines as a potential model system for the carbohydrate-mediated interaction between the ookinete and mosquito midgut. Lectin binding coupled with respective sugar inhibitions, and glycosidase enzyme in situ treatments can provide much information about oligosaccharide structures present on glycoproteins from a given cell or tissue type [12].

The anopheline cell lines showed a limited glycosylation profile with only a few different types of oligosaccharides. A summary of oligosaccharides detected on $A n$. stephensi 43 cell line and An. gambiae 55 cell line glycoproteins are shown in Tables 3 and 4 respectively. The most common, the oligomannose $\left(\mathrm{Man}_{8-5}\right)$ was susceptible to both PNGase $\mathrm{F}$ and Endo $\mathrm{H}$ treatment and was present on fifteen An. stephensi 43 cell line proteins, and twelve An. gambiae 55 cell line proteins. Oligosaccharides were also present that were susceptible to PNGase 
A

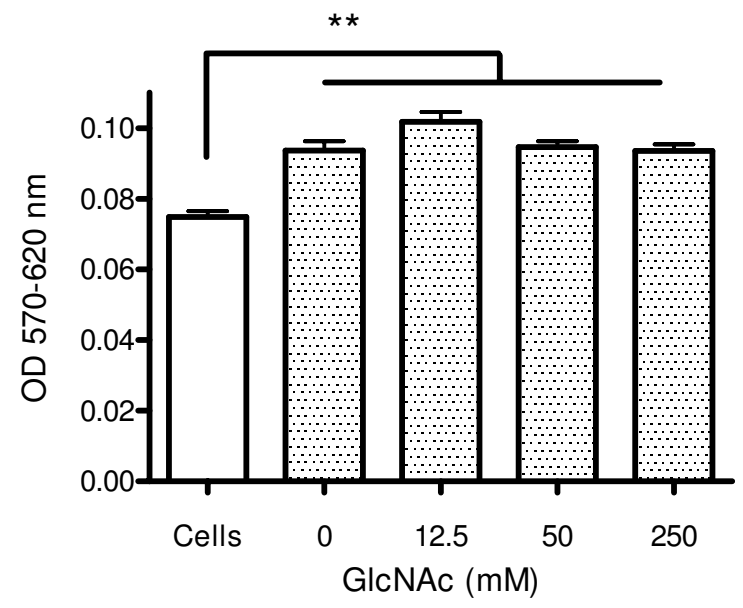

B

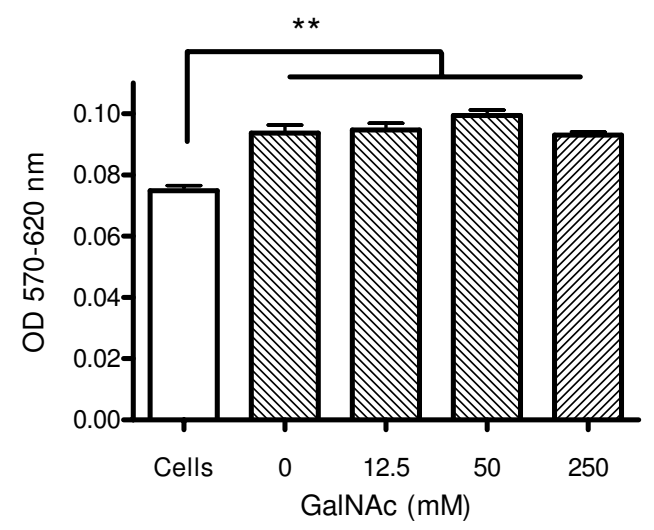

$\mathrm{C}$

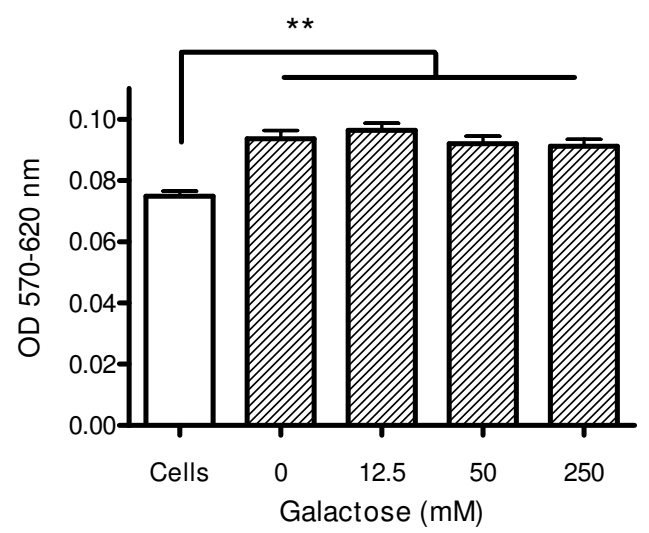

Figure 7 Effect of different carbohydrates on the binding of $P$. berghei ookinetes to methanol-fixed An. stephensi 43 cells. Numbers of cells per ml of culture were estimated using a haemocytometer. 300,000 cells were added to each microwell, allowed to settle, then fixed with a $30 \mathrm{~s}$ treatment with methanol. 20,000 ookinetes in culture were added to each well and incubated in the presence or absence of carbohydrates for $6 \mathrm{~h}$ at $19^{\circ} \mathrm{C}$. Following a washing step, $100 \mu \mathrm{l}$ of PBS and $10 \mu \mathrm{l}$ of MTT was added and the plates incubated for a further $4 \mathrm{~h}$ at $37^{\circ} \mathrm{C}$. Plates were then read at 570 and $620 \mathrm{~nm}$. Data shown are representative of three assays carried out. Plate readings were zeroed to a PBS blank. Shading indicates wells where ookinetes were added. ${ }^{* *}$ Ookinete binding to cells was significantly higher than the control of cells alone $(p<0.01$; One-way ANOVA, Dunnett's post hoc test). Data +/- SEM ( $n=5-6)$. Figure 7A: Binding to cells alone, and GlcNAc at 0, 12.5, 50 and 250 mM. Figure 7B: Binding to cells alone, and GalNAc at 0, 12.5, 50 and $250 \mathrm{mM}$. Figure 7C: Binding to cells alone, and Galactose at 0, 12.5, 50 and $250 \mathrm{mM}$. 
F, Endo $\mathrm{H}$ and also bound AAL, a fucose specific lectin. The binding indicated the presence of core fucosylation when AAL binding was abolished with PNGase F treatment. However PNGase F is not capable of cleaving $N$ linked oligosaccharides that have $\alpha 1-3$ core fucosylation [33], so the fucosylation present on these glycoproteins may be $\alpha 1-6$ linked. This type of fucosylation is more typical of mammalian glycoproteins, although lepidopteran arylphorin and Drosophila melanogaster chaoptin glycoproteins express the same fucosylation linkage [34,35]. Chemical treatment with periodate before blotting removed all Con A binding sites on all mosquito cell line glycoproteins confirming the presence of adjacent hydroxyl groups within pyranose ring structures such as those found in mannose [36].

In both cell lines PNGase F reduced JAC binding, most clearly in An. gambiae 55 cell line glycoproteins. This suggests that oligosaccharides were present with either GalNAc $\beta 1-3 G a l$ or Gal $\beta 1-3 G a l N A c$ residues were $N$ linked to the protein. Similar oligosaccharide structures have been detected previously in the venom of the honey bee Apis mellifera [37]. PNGase F reduced JAC binding to An. stephensi 43 cell line glycoproteins suggesting some residues recognised by JAC were $O$-linked e.g. GalNAc linked directly to the protein. Binding of PNA was abolished by $O$-glycanase suggesting that Gal $\beta 1-3 \mathrm{GalNAc}$ was linked directly to the protein on the An. stephensi 43 cell line $87 \mathrm{kDa}$ glycoprotein. Binding of DBA to An. gambiae 55 cell line proteins suggested the presence of GalNAc residues $O$-linked directly to the protein.

Treatments with PNGase F and $\beta$-galactosidase prior to $\mathrm{RCA}_{\mathrm{II}}$ lectin binding indicated the presence of N-linked complex or hybrid oligosaccharides with terminal Gal $\beta 1$ 4GlcNAc on an An. stephensi 43 cell line glycoprotein. Although SNA bound to glycoproteins from both cell lines, sialic acid did not inhibit binding, and in some cases $100 \mathrm{mM}$ Sialic acid appeared to enhance SNA binding to certain bands. It is not possible to draw firm conclusions as to the presence of sialic acid within the two mosquito cell lines. The presence or absence of sialic acid within insect cells has been a source of contention for many years (reviewed in [38]).

Oligosaccharides synthesised by insect cells differ from those synthesised by mammalian cells, for example an Aedes albopictus cell line, which lacks the transferases necessary to make complex-type oligosaccharides, add oligomannose structures to a protein glycosylation site which in mammalian cells would have a complex-type oligosaccharide added [39]. The anopheline cell lines used in this study showed a limited range of glycosylation consistent with other insect cell lines e.g. Ae. aegypti 20A cells [40]. The fibroblast-like anopheline cells were derived from unknown tissues of first-stage mosquito larvae $[22,23]$, and were originally cultured to be suitable for the study of malaria parasites and arboviruses [23]. The presence on mosquito cell line surfaces of a glycoprotein recognised by malarial ookinetes would provide a source of substrates for further molecular investigations of ookinete binding, a potential transmission blocking vaccine target, and a useful model for studying ookinete:mosquito midgut interactions in vitro. Identification of mosquito midgut surface carbohydrate epitopes have proved useful in understanding the interactions between the mosquito midgut and both arboviruses and the malaria parasite $[16,41]$.

P. berghei ookinetes bound to both cell lines but although significant, the binding was at the limit of detection and at the lower limit of the linear relationship between MTT absorbance and ookinete number. Binding was not carbohydrate inhibitable with GlcNAc, GalNAc or galactose concentrations of up to $250 \mathrm{mM}$, suggesting a non-carbohydrate mediated binding. This binding could be through a ligand other than the oligosaccharides expressed on the mosquito cell line glycoproteins such as laminin or the proteoglycan chondroitin sulphate $[42,43]$.

The question remains as to why anopheline cell lines did not provide a suitable model for ookinete binding. Although both cell lines expressed several oligosaccharides in common with the mosquito midgut, e.g. oligomannose, the primary and most important difference from the glycosylation of the mosquito midgut was the apparent lack of abundant terminal GlcNAc and GalNAc residues on cell line oligosaccharides. The interaction between the malarial ookinete and the mosquito midgut is complex and multi-faceted. Previous work suggested that there might be a lectin-like molecule on the ookinete surface [17]. Ookinetes of P. berghei bound to neoglycoproteins rich in GlcNAc residues, and GlcNAc and GalNAc reduced the infectivity of $P$. berghei ookinetes to $A n$. stephensi mosquitoes [44,45]. The surface of Ae. aegypti and $A n$. stephensi midgut microvilli are rich in both GlcNAc and GalNAc [12,31]. Carbohydrates could not be detected on either P. gallinaceum or P. berghei ookinetes [31]. This and other evidence suggests that a lectin-carbohydrate interaction exists and the lectin is on the ookinete surface $[13,14,16]$. It is likely that the lack of GlcNAc- and GalNAc-containing oligosaccharides from anopheline cell line glycoproteins was a contributing factor to the unsuitability of the cell lines as a model for ookinete:mosquito midgut binding.

In conclusion, although anopheline mosquito cell lines express some oligosaccharides common to the mosquito midgut, the cells are not a model system suitable for studying the binding of $P$. berghei ookinetes. These observations reinforce indirectly the importance of the presence of GlcNAc and GalNAc residues in the critical life cycle interaction between malarial ookinetes and the mosquito midgut. 
Table 3: Summary of oligosaccharides found on An. stephensi 43 cell line glycoproteins

\begin{tabular}{|c|c|c|c|}
\hline \multirow{2}{*}{$\begin{array}{c}\text { Glycoprotein approx. } \\
\text { kDa }\end{array}$} & \multicolumn{2}{|c|}{ N-linked } & \multirow[t]{2}{*}{ O-linked } \\
\hline & Oligomannose/Hybrid & Complex & \\
\hline 370 & $\begin{array}{l}\text { Oligomannose/hybrid } \pm \text { a1- } \\
\text { 6Fuc }\end{array}$ & $\begin{array}{l}\text { Galß1-3GalNAc } \\
\text { GalNAc } \beta 1-3 G a l\end{array}$ & GalNAca $/ \beta-$ \\
\hline 138 & $\begin{array}{l}\text { Oligomannose/hybrid } \pm \text { a1- } \\
\text { 6Fuc }\end{array}$ & & \\
\hline 122 & & $\begin{array}{l}\text { Galß1-3GalNAc } \\
\text { GalNAc } \beta 1-3 G a l\end{array}$ & GalNAca/ $\beta-$ \\
\hline 117 & $\begin{array}{l}\text { Oligomannose/hybrid } \pm \text { a1- } \\
6 \text { Fuc }\end{array}$ & & \\
\hline 111 & & $\begin{array}{l}\text { Gal } \beta 1-3 G \text { alNAc } \\
\text { GalNAc } \beta 1-3 G a l\end{array}$ & GalNAca/ $\beta-$ \\
\hline 103 & Oligomannose & & \\
\hline 87 & $\begin{array}{l}\text { Oligomannose/hybrid } \pm \text { a1- } \\
6 \text { Fuc }\end{array}$ & $\begin{array}{l}\text { Gal } \beta 1-3 G \text { alNAc } \\
\text { GalNAc } \beta 1-3 G a l \\
\text { Gal } \beta 1-4 R\end{array}$ & $\begin{array}{l}\text { Galß1-3GalNAc } \\
\text { GalNAca } \beta \text { - }\end{array}$ \\
\hline 79 & Hybrid \pm a1-6Fuc & & \\
\hline 67 & Oligomannose & & \\
\hline 59 & $\begin{array}{l}\text { Oligomannose/hybrid } \pm \text { a1- } \\
\text { 6Fuc }\end{array}$ & & \\
\hline 55 & & $\begin{array}{l}\text { Galß1-3GalNAc } \\
\text { GalNAc } \beta 1-3 G \text { al }\end{array}$ & GalNAca/ $\beta$ - \\
\hline 52 & $\begin{array}{l}\text { Oligomannose/hybrid } \pm \text { a1- } \\
\text { 6Fuc }\end{array}$ & $\begin{array}{l}\text { Galß1-3GalNAc } \\
\text { GalNAc } \beta 1-3 G a l\end{array}$ & GalNAca $/ \beta-$ \\
\hline 48 & Oligomannose & $\begin{array}{l}\text { Galß1-3GalNAc } \\
\text { GalNAc } \beta 1-3 G a l\end{array}$ & GalNAca $/ \beta-$ \\
\hline 45 & $\begin{array}{l}\text { Oligomannose/hybrid } \pm \text { a1- } \\
\text { 6Fuc }\end{array}$ & & \\
\hline 42 & $\begin{array}{l}\text { Oligomannose/hybrid } \pm \text { a1- } \\
\text { 6Fuc }\end{array}$ & & \\
\hline 39 & Oligomannose & & \\
\hline 36 & $\begin{array}{l}\text { Oligomannose/hybrid } \pm \text { a1- } \\
6 \text { Fuc }\end{array}$ & & \\
\hline 34 & & $\begin{array}{l}\text { Galß1-3GalNAc } \\
\text { GalNAc } \beta 1-3 G a l\end{array}$ & GalNAca/ $\beta-$ \\
\hline 33 & Oligomannose & & \\
\hline 33 & Oligomannose & $\begin{array}{l}\text { Galß1-3GalNAc } \\
\text { GalNAc } \beta 1-3 G a l\end{array}$ & GalNAca/ $\beta-$ \\
\hline 30 & Oligomannose & & \\
\hline
\end{tabular}

\section{Conclusions}

Using an array of lectins and glycosidases, we have shown the presence of a number of different oligosaccharides on glycoproteins expressed by two anopheline cell lines, $A n$. stephensi 43 and An. gambiae 55. In addition we showed that $P$. berghei ookinetes bound poorly to monolayers of both anopheline cell lines but the binding was not inhibitable by monosaccharides. The different pattern of gly- cosylation observed in the cells compared with the mosquito midgut is a likely reason the ookinetes did not bind suggesting anopheline cell lines are not suitable as a model for the ookinete:mosquito midgut interaction. This study highlights the importance of GlcNAc and GalNAc oligosaccharides present on the mosquito midgut in the critical life cycle step for the malarial ookinete of traversing the midgut. 
Table 4: Summary of oligosaccharides found on An. gambiae 55 cell line glycoproteins

\begin{tabular}{|c|c|c|c|}
\hline \multirow{2}{*}{$\begin{array}{c}\text { Glycoprotein approx. } \\
\text { kDa }\end{array}$} & \multicolumn{2}{|c|}{$\mathbf{N}$-linked } & \multirow[t]{2}{*}{ O-linked } \\
\hline & Oligomannose/Hybrid & Complex & \\
\hline 182 & Oligomannose & & \\
\hline 143 & $\begin{array}{l}\text { Oligomannose/hybrid } \pm \text { a1- } \\
\text { 6Fuc }\end{array}$ & & \\
\hline 114 & $\begin{array}{l}\text { Oligomannose/hybrid } \pm \text { a1- } \\
\text { 6Fuc }\end{array}$ & GaINAc $\beta 1-3 G a l$ & \\
\hline 101 & Oligomannose/hybrid & GalNAc $\beta 1-3 G a l$ & \\
\hline 87 & & $\begin{array}{l}\text { Galß1-3GalNAc } \\
\text { GalNAc } \beta 1-3 G a l\end{array}$ & \\
\hline 76 & $\begin{array}{l}\text { Oligomannose/hybrid } \pm \text { a1- } \\
\text { 6Fuc }\end{array}$ & GalNAc $\beta 1-3 G a l$ & GalNAca/ $\beta-$ \\
\hline 65 & Oligomannose & & \\
\hline 61 & & $\begin{array}{l}\text { Galß1-3GalNAc } \\
\text { GalNAc } \beta 1-3 G a l\end{array}$ & \\
\hline 58 & $\begin{array}{l}\text { Oligomannose/hybrid } \pm \text { a1- } \\
6 \text { Fuc }\end{array}$ & GalNAc $\beta 1-3 \mathrm{Gal}$ & \\
\hline 55 & Oligomannose & & \\
\hline 54 & & $\begin{array}{l}\text { Galß1-3GalNAc } \\
\text { GalNAc } \beta 1-3 G a l\end{array}$ & GalNAca/ $\beta-$ \\
\hline 50 & Oligomannose & & \\
\hline 45 & Oligomannose & & \\
\hline 38 & Oligomannose & & \\
\hline 36 & & & GalNAca/ $\beta-$ \\
\hline 35 & Oligomannose & $\begin{array}{l}\text { Galß1-3GalNAc } \\
\text { GalNAc } \beta 1-3 G a l\end{array}$ & GalNAca/ $\beta-$ \\
\hline
\end{tabular}

\section{Abbreviations}

aAGA: a-N-acetylgalactosaminidase; AAL: Aleutia aurantia agglutinin; AP: alkaline phosphatase; ASF: asialofetuin; ASM: asialomucin; Asn: asparagine; BCIP: 5 bromo-4-chloro-3'-indolyl phosphate sodium salt; BSA-T: Galß1-3GalNACBovine serum albumin; Con A: Concanavalin A; DBA: Dolichos biflorus agglutinin; Endo $\mathrm{H}$ : endo- $\beta-\mathrm{N}$-acetylglucosaminidase $\mathrm{H}$; Fuc: fucose; Gal: galactose; GalNAc: N-acetylgalactosamine; GlcNAc: N-acetylglucosamine; Glc: glucose JAC: Artocarpus integrifolia agglutinin; kDa: kilo Dalton; LPG: lipophosphoglycan (from Leishmania major promastigotes); M: melibiose; MAL lectin; Man: mannose; MTT: 3-[4,5-dimethylthiazol-2-yl)-2,5-diphenyl tetrazolium bromide; NBT: nitro-blue tetrazolium chloride; NCM: nitrocellulose membrane; O-glycanase ${ }^{\mathrm{TM}}$ : Endo- $\mathrm{a}-\mathrm{N}$-acetylgalactosaminidase; PBS: physiologically buffered saline; PHA: Phaesolus vulgaris agglutinin; PNGase A/F: peptide -N4-(Nacetyl- $\beta$-glucosaminyl)-asparagine amidase $A / F ; R C A_{\|}$: Ricinus communis agglutinin; PNA: Peanut agglutinin; SBA: Soybean agglutinin; SD: standard deviation; Ser: serine; SNA: Sambuca nigra agglutinin; TBS: tris-buffered saline; TBS-T: tris-buffered saline with Tween 20; Thr: threonine; UEA; Ulex europaeus agglutinin; WGA: wheat germ agglutinin.

\section{Competing interests}

The authors declare that they have no competing interests.

\section{Authors' contributions}

SW carried out the experiments and drafted the manuscript. PFB conceived of the study, participated in experimental design and helped draft the manuscript. All authors read and approved the final manuscript.

\section{Acknowledgements}

We thank Dr. R. P. Lane, and Dr. A. Emery for their advice and discussions. The two cell lines were the kind gift of Dr. C. Leake, London School of Hygiene and Tropical Medicine, London, UK and we are grateful to Hedi Otten and Nadia Lotfy for assistance in cell culture. The research was supported by the Royal Society, BBSRC (Case award with Natural History Museum, London, UK), and the Wellcome Trust (Grant no. 037110/Z/92/2).

\section{Author Details}

'Department of Biology, Imperial College of Science Technology and Medicine, South Kensington, London, SW7 2BB, UK, 2 Monash Institute of Medical Research, Monash University, Melbourne, VIC, 3168, Australia and 3Sanaria Inc., 9800 Medical Center Drive, Suite A209, Rockville, MD, 20850, USA

Received: 25 January 2010 Accepted: 25 March 2010

Published: 25 March 2010

\section{References}

1. Knell AJ: Malaria Oxford: Oxford University Press; 1991

2. Pradel G: Proteins of the malaria parasite sexual stages: expression, function and potential for transmission blocking strategies. Parasitology 2007, 134:1911-1929.

3. Lavazec C, Bourgouin C: Mosquito-based transmission blocking vaccines for interrupting Plasmodium development. Microbes Infect 2008, 10:845-849.

4. Waitumbi JN, Anyona SB, Hunja CW, Kifude CM, Polhemus ME, Walsh DS, Ockenhouse CF, Heppner DG, Leach A, Lievens M, Ballou WR, Cohen JD, 
Sutherland CJ: Impact of RTS, S/AS02(A) and RTS, S/AS01(B) on genotypes of $P$. falciparum in adults participating in a malaria vaccine clinical trial. PLoS One 2009, 4:e7849.

5. Abraham EG, Jacobs-Lorena M: Mosquito midgut barriers to malaria parasite development. Insect Biochem Mol Biol 2004, 34:667-671.

6. Baton LA, Ranford-Cartwright LC: How do malaria ookinetes cross the mosquito midgut wall? Trends Parasitol 2005, 21:22-28

7. Jaramillo-Gutierrez G, Rodrigues J, Ndikuyeze G, Povelones M, MolinaCruz A, Barillas-Mury C: Mosquito immune responses and compatibility between Plasmodium parasites and anopheline mosquitoes. BMC Microbiol 2009, 9:154.

8. Dawes EJ, Churcher TS, Zhuang S, Sinden RE, Basanez MG: Anopheles mortality is both age- and Plasmodium-density dependent: implications for malaria transmission. Malar J 2009, 8:228

9. Jurat-Fuentes $\mathrm{JL}$, Gould FL, Adang MJ: Altered Glycosylation of 63- and 68-kilodalton microvillar proteins in Heliothis virescens correlates with reduced Cry 1 toxin binding, decreased pore formation, and increased resistance to Bacillus thuringiensis Cry1 toxins. Appl Environ Microbio 2002, 68:5711-5717.

10. Tellam RL, Vuocolo T, Eisemann C, Briscoe S, Riding G, Elvin C, Pearson R: Identification of an immuno-protective mucin-like protein, peritrophin-55, from the peritrophic matrix of Lucilia cuprina larvae. Insect Biochem Mol Biol 2003, 33:239-252.

11. Dinglasan RR, Jacobs-Lorena M: Insight into a conserved lifestyle: protein-carbohydrate adhesion strategies of vector-borne pathogens. Infect Immun 2005, 73:7797-7807.

12. Wilkins S, Billingsley PF: Partial characterization of oligosaccharides expressed on midgut microvillar glycoproteins of the mosquito, Anopheles stephensi Liston. Insect Biochem Mol Biol 2001, 31:937-948.

13. Ramasamy MS, Kulasekera R, Wanniarachchi IC, Srikrishnaraj KA, Ramasamy R: Interactions of human malaria parasites, Plasmodium vivax and $P$. falciparum, with the midgut of Anopheles mosquitoes. Medical and Veterinary Entomology 1997, 11:290-296.

14. Zieler H, Nawrocki JP, Shahabuddin M: Plasmodium gallinaceum ookinetes adhere specifically to the midgut epithelium of Aedes aegypti by interaction with a carbohydrate ligand. J Exp Biol 1999 202:485-495.

15. Trueman HE, Raine JD, Florens L, Dessens JT, Mendoza J, Johnson J, Waller CC, Delrieu I, Holder AA, Langhorne J, Carucci DJ, Yates JR, Sinden RE: Functional characterization of an LCCL-lectin domain containing protein family in Plasmodium berghei. J Parasitol 2004, 90:1062-1071.

16. Dinglasan RR, Fields I, Shahabuddin M, Azad AF, Sacci JB Jr: Monoclonal antibody MG96 completely blocks Plasmodium yoelii development in Anopheles stephensi . Infect Immun 2003, 71:6995-7001.

17. Billingsley PF: Vector-parasite interactions for vaccine development. International Journal for Parasitology 1994, 24:53-58.

18. Sousa MC, Goncalves CA, Bairos VA, Poiares-Da-Silva J: Adherence of Giardia lamblia trophozoites to Int-407 human intestinal cells. Clin Diagn Lab Immunol 2001, 8:258-265.

19. Tavares P, Rigothier MC, Khun H, Roux P, Huerre M, Guillen N: Roles of cell adhesion and cytoskeleton activity in Entamoeba histolytica pathogenesis: a delicate balance. Infect Immun 2005, 73:1771-1778.

20. Knowles BH, Knight PJK, Ellar DJ: $\mathrm{N}$-acetylgalactosamine is part of the receptor in insect gut epithelia that recognises an insecticidal protein from Bacillus thuringiensis. Proceedings of the Royal Society, London 1991, 245:31-35.

21. Zhang MY, Lövgren A, Landén R: Adhesion and cytotoxicity of Bacillus thuringiensis to cultured Spodoptera and Drosophila cells. Journal of Invertebrate Pathology 1995, 66:46-51.

22. Pudney M, Varma MG: Anopheles stephensi var. mysorenis: establishment of a larval cell line (Mos. 43). Exp Parasitol 1971, 29:7-12.

23. Pudney M, Marhoul Z, Varma MG, Leake CJ: A continuous mosquito cell line from larvae of Anopheles gambiae. Trans R Soc Trop Med Hyg 1972, 66:21-22.

24. Bradford M: A rapid and sensitive method for the quantitation of microgram quantities of protein utilizing the principle of protein-dye binding. Analytical Biochemistry 1976, 72:248.

25. Laemmli UK, Favre M: Maturation of the Head of Bacteriophage T4. 1. DNA Packaging Events. Journal of Molecular Biology 1973, 80:575-599.

26. Sinden RE: Infection of mosquitoes with rodent malaria. In Molecular Biology of Insect Disease Vectors: A Methods Manual Edited by: Crampton JM, Beard CB, Louis C. London: Chapman and Hall; 1997:67-91.
27. Mossman T: Rapid Colorimetric Assay for Cellular Growth and Survival: Application to Proliferation and Cytoxicity Assays. Journal of Immunological Methods 1983, 65:55-63.

28. Ranawaka G, Alejo Blanco R, Sinden RE: The effect of transmissionblocking antibody ingested in primary and secondary bloodfeeds, upon the development of Plasmodium berghei in the mosquito vector. Parasitology 1993, 107:225-231

29. Fauquenoy S, Morelle W, Hovasse A, Bednarczyk A, Slomianny C, Schaeffer C, Van Dorsselaer A, Tomavo S: Proteomics and glycomics analyses of $\mathrm{N}$ glycosylated structures involved in Toxoplasma gondii--host cell interactions. Mol Cell Proteomics 2008, 7:891-910.

30. Silva BA, Pereira FM, de Jesus JB, Branquinha MH, Santos AL, d'Avila-Levy CM: Sialoglycoconjugates in Herpetomonas megaseliae: role in the adhesion to insect host epithelial cells. FEMS Microbiol Lett 2009

31. Rudin W, Hecker H: Lectin-binding sites in the midgut of the mosquitoes Anopheles stephensi Liston and Aedes aegypti L. (Diptera: Culicidae). Parasitological Research 1989, 75:268-279.

32. Dinglasan RR, Kalume DE, Kanzok SM, Ghosh AK, Muratova O, Pandey A, Jacobs-Lorena M: Disruption of Plasmodium falciparum development by antibodies against a conserved mosquito midgut antigen. Proc Natl Acad Sci USA 2007, 104:13461-13466

33. Tretter V, Altmann F, März L: Peptide-N4-(N-acetyl- $\beta$ glucosaminyl)asparagine amidase $\mathrm{F}$ cannot release glycans with fucose attached a1-3 to the asparagine-linked $\mathrm{N}$-acetylglucosamine residue. European Journal of Biochemistry 1991, 199:647-652.

34. Kim HG, Yang SM, Lee YC, Do SI, Chung IS, Yang JM: High-level expression of human glycosyltransferases in insect cells as biochemically active form. Biochem Biophys Res Commun 2003, 305:488-493.

35. Kanie Y, Yamamoto-Hino M, Karino Y, Yokozawa H, Nishihara S, Ueda R Goto S, Kanie O: Insight into the regulation of glycan synthesis in Drosophila chaoptin based on mass spectrometry. PLoS One 2009, 4:e5434.

36. Woodward MP, Young J, W W, Bloodgood RA: Detection of Monoclonal Antibodies Specific for Carbohydrates Epitopes Using Periodate Oxidation. Journal of Immunological Methods 1985, 78:143-153.

37. Kubelka V, Altmann F, Staudacher E, Tretter V, März L, Hård K, Kamerling JP, Vliegenhart JFG: Primary structures of the $N$-linked carbohydrate chains from honeybee venom phospholipase A2. European Journal of Biochemistry 1993, 213:1193-1204.

38. Koles K, Repnikova E, Pavlova G, Korochkin LI, Panin VM: Sialylation in protostomes: a perspective from Drosophila genetics and biochemistry. GlycoconjJ 2009, 26:313-324.

39. Hsieh P, Robbins PW: Regulation of the asparagine-linked oligosaccharides processing in Aedes albopictus mosquito cells. Journal of Biological Chemistry 1984, 259:2375-2382.

40. Butters TD, Hughes RC: Lectin binding to mosquito Aedes aegypti and human KB cells: Structural comparisons of membrane oligosaccharides. Carbohydrate Research 1978, 61:159-168.

41. Foy B, Killeen G, Frohn R, Impoinvil D, Williams A, Beier J: Characterisation of a unique human single-chain antibody isolated by phage-display selection on membrane-bound mosquito midgut antigens. J Immunol Methods 2002, 261:

42. Dinglasan R, Alaganan A, Ghosh A, Saito A, van Kuppevelt T, JacobsLorena M: Plasmodium falciparum ookinetes require mosquito midgut chondroitin sulfate proteoglycans for cell invasion. Proc Natl Acad Sci USA 2007, 104:15882-15887.

43. Nacer A, Walker $\mathrm{K}$, Hurd H: Localisation of laminin within Plasmodium berghei oocysts and the midgut epithelial cells of Anopheles stephensi. Parasites and Vectors 2008, 1:33

44. Billingsley PF: Approaches to vector control: new and trusted. 2 . Molecular targets in the insect midgut. Trans R Soc Trop Med Hyg 1994, 88:136-140.

45. Wilkins S, Billingsley PF: Binding of Plasmodium berghei ookinetes to synthetic and natural glycoconjugates [abstract]. Ann Trop Med Parasitol 1996, 90:422.

46. Becker JW, GN Reecke J, Cunningham BA, Edelman GM: New evidence on the location of the saccharide-binding site of Concanavalin A. Nature 1976, 259:406-409.

47. Allen AK, Neuberger A, Sharon N: The purification, composition and specificity of Wheat-Germ Agglutinin. Biochemical Journal 1973, 131:155-162. 
48. Baker DA, Sungii S, Kabat EA, Ratcliffe RM, Hermetin P, Lemieux RU: Immunochemical studies on the combining sites of Forssman hapten reactive haemagglutinins from Dolichos biflorus, Helix pomatia, and Wisteria floribunda. Biochemistry 1983, 22:2741-2750.

49. Lotan R, Siegelman HW, Lis H, Sharon N: Subunit structure of soybean agglutinin. Journal of Biological Chemistry 1974, 249:1219-1224.

50. Lotan R, Skutelsky E, Danon D, Sharon N: The purification, composition and specificity of the anti-T lectin from peanut (Arachis hypogaea). Journal of Biological Chemistry 1975, 250:8518-8523.

51. Ahmed $H$, Chatterjee BP: Further characterisation and immunochemical studies on the carbohydrate specificity of Jackfruit (Artocarpus integrifolia) lectin. Journal of Biological Chemistry 1989, 264:9365-9372.

52. Wu AM, Wu JH, Lin LH, Lin SH, Liu JH: Binding profile of Artocarpus integrifolia agglutinin (Jacalin). Life Sci 2003, 72:2285-2302.

53. Kornfeld R, Kornfeld S: The structure of a phytohaemagglutinin receptor site from human erythrocytes. Journal of Biological Chemistry 1970, 245:2536-2545

54. Nicolson GL, Blaustein J: The interaction of Ricinus communis agglutinin with normal and tumor cell surfaces. Biochimica et Biophysica Acta 1972, 266:543-547.

55. Wang WC, Cummings RD: The immobilized leukoagglutinin from the seeds of Maackia amurensis binds with high affinity to complex-type Asn-linked oligosaccharides containing terminal sialic acid-linked a2,3 to penultimate galactose residues. Journal of Biological Chemistry 1988, 263:4576-4685.

56. Shibuya N, Goldstein IJ, Broekart WF, Nsimba-Lubaki M, Peeters B, Peumans WJ: The Elderberry (Sambuca nigra L.) Bark Lectin Recognises the Neu5Ac(a2-6)Gal/GalNac Sequence. Journal of Biological Chemistry 1987, 262:1596-11987.

57. Pereira MEA, Kisailus EC, Gruezo F, Kabat EA: Immunochemical Studies on the Combining Site of the Blood Group H-Specific Lectin 1 from Ulex europeus seeds. Archives of Biochemistry and Biophysics 1978 185:108-115.

58. Debray $\mathrm{H}$, Montreuil J: Aleuria aurantia agglutinin. A new isolation procedure and further study of its specificity towards various glycopeptides and oligosaccharides. Carbohydrate Research 1989, 185:15-26.

59. Elder $\mathrm{JH}$, Alexander S: endo- $\beta-\mathrm{N}$-Acetylglucosaminidase $\mathrm{F}$ : Endoglycosidase from Flavobacterium meningosepticum that cleaves both high-mannose and complex glycoproteins. Proceedings of the National Academy of Science USA 1982, 79:4540-4544.

60. Plummer TH, Phelan AW, Tarentino AL: Detection and quantification of peptide-N4-( $N$-acetyl- $\beta$-glucosaminyl) asparagineamidases. European Journal of Biochemistry 1987, 163:167-173.

61. Tarentino AL, Maley F: Purification and Properties of an Endo- $\beta-N$ acetylglucosaminidase from Streptomyces griseus. Journal of Biological Chemistry 1974, 249:811-817.

62. Bhavanadan VP, Umemoto J, Davidson EA: Characterisation of an endoa- $N$-acetylgalactosaminidase from Diplococcus pneumoniae . Biochemical and Biophysical Research Communications 1976, 70:738-745.

63. Zhu A, Goldstein J: Cloning and characterisation of a cDNA encoding chicken liver a- $N$-acetylgalactosaminidase. Gene 1993, 137:309-314.

64. Paulson JC: Sialyl- and fucosyltransferases in the biosynthesis of asparaginyl-linked oligosaccharides in glycoproteins. Journal of Biological Chemistry 1978, 253:5617-5524.

65. Schauer R, Nöhle U: Sialidase (Neuraminidase). In Methods of enzymatic analysis Volume 4. 3rd edition. Edited by: Bergmeyer HU. Weinheim: Verlag Chemie; 1984:195-208.

doi: $10.1186 / 1756-3305-3-22$

Cite this article as: Wilkins and Billingsley, Mosquito cell line glycoproteins: an unsuitable model system for the Plasmodium ookinete-mosquito midgut interaction? Parasites \& Vectors 2010, 3:22

\section{Submit your next manuscript to BioMed Central} and take full advantage of:

- Convenient online submission

- Thorough peer review

- No space constraints or color figure charges

- Immediate publication on acceptance

- Inclusion in PubMed, CAS, Scopus and Google Scholar

- Research which is freely available for redistribution

Submit your manuscript at www.biomedcentral.com/submit
C Biomed Central 